\title{
BIAYA TRANSAKSI DAN NILAI TAMBAH PADA RANTAI PASOK DAGING SAPI DI KOTA BOGOR
}

\author{
Nadya Megawati Rachman*)1, Eko Ruddy Cahyadi**), dan Hartrisari Hardjomidjojo ${ }^{* * *)}$ \\ *) Program Studi Ilmu Manajemen, Institut Pertanian Bogor \\ Gedung FEM Lantai 2, Jl. Kamper, Kampus IPB Dramaga, Bogor 16680 \\ **) Departemen Manajemen, Fakultas Ekonomi dan Manajemen, Institut Pertanian Bogor \\ Jl. Raya Darmaga, Kampus IPB Darmaga, Bogor 16680 \\ ${ }^{* * *}$ Departemen Teknologi Industri Pertanian, Fakultas Teknologi Pertanian, Institut Pertanian Bogor \\ Gedung Fateta Lantai 2, Kampus IPB Dramaga, Bogor 16680
}

\begin{abstract}
The objectives of this study are to map the distribution network of beef supply chain in Bogor city and analyze the transaction cost, value added and marketing efficiency in the marketing channel of beef supply chain in Bogor city. Value stream mapping (VSM) was used to analyze the distribution channel of beef supply chain. Hayami method was used to analyze transaction cost, value added and marketing efficiency. The result shows that there are 9 alternative distribution channels of beef marketing in Bogor city. The biggest value added gained by PBDS I (22.24\%) is from slaughtering activities. Transaction cost in supply chain process is only 3-5\% the total costs. The dominating cost is the cost to buy beef supply (60\%), and the most efficient and profitable channel is channel 7 (Feedloter-PBDSI-Consumer) with the marketing efficiency score of $0.80 \%$. Therefore, the butchers in Bogor city are recommended to choose channel 7 for its highest benefit and efficient channel.
\end{abstract}

Keywords: beef, supply chain, transaction cost, value added, hayami method

\begin{abstract}
ABSTRAK
Tujuan dari penelitian ini adalah memetakan jaringan distribusi rantai pasok daging sapi di Kota Bogor dan menganalisis biaya transaksi, nilai tambah dan tingkat efisiensi pemasaran dari saluran pemasaran daging sapi di Kota Bogor. Value stream mapping (VSM) digunakan untuk memetakan jaringan distribusi daging sapi dan metode hayami digunakan untuk menganalisis biaya transaksi, nilai tambah dan efisiensi pemasaran. Berdasarkan hasil pemetaan jaringan distribusi rantai pasok daging sapi dengan menggunakan VSM terdapat sembilan alternatif saluran distribusi pemasaran daging sapi di Kota Bogor. Nilai tambah terbesar diperoleh dari hasil pemotongan sapi hidup menjadi karkas yang didapatkan oleh PBDS I (22,24\%). Biaya transaksi dalam proses pasokan jaringan distribusi hanya berkisar 3-5\% dari total biaya yang dikeluarkan. Biaya yang mendominasi adalah biaya dalam membeli pasokan daging sapi yang mencapai 60\%. Saluran pemasaran daging sapi yang paling efisien dan menguntungkan adalah saluran 7 (Feedloter - PBDS I - Konsumen) dengan skor efisiensi pemasaran sebesar 0,80\%. Oleh karena itu, pedagang daging sapi Kota Bogor disarankan untuk memilih saluran 7 untuk mendapatkan keuntungan yang paling tinggi dan paling efisien.
\end{abstract}

Kata kunci: daging sapi, rantai pasok, biaya transaksi, nilai tambah, metode hayami

\footnotetext{
${ }^{1}$ Alamat Korespondensi:

Email: nadyanamera@gmail.com
} 


\section{PENDAHULUAN}

Pasar dan perdagangan merupakan dua aspek yang saling terkait dan saling mengisi. Peluang pasar hanya dapat dimanfaatkan secara maksimal jika didukung oleh sistem perdagangan yang efisien (Aisyah et al. 2013). Efisiensi kegiatan distribusi komoditas sangat dipengaruhi oleh panjang mata rantai distribusi dan besarnya margin keuntungan yang ditetapkan oleh setiap mata rantai distribusi (Sirait et al. 2007). Semakin pendek mata rantai distribusi dan semakin kecil selisih margin keuntungan antar pelaku pasokan maka kegiatan distribusi tersebut semakin efisien. Adanya saluran distribusi daging sapi yang melibatkan beberapa pelaku atau lembaga penyalur dikarenakan jarak yang jauh antara produsen dan konsumen. Menurut Emhar et al. (2014) pada dasarnya aktivitas rantai pasok atau rantai distribusi daging sapi dalam menyalurkan produk dari peternak hingga ke konsumen akhir daging sapi akan menciptakan nilai yang menguntungkan. Nilai tambah ini menjadi daya tarik dalam bisnis daging sapi. Harga daging di tingkat pengecer atau konsumen sangat ditentukan oleh harga pokok (di tingkat produsen), biaya penambahan nilai, biaya transaksi, keuntungan lembaga yang terlibat dan keseimbangan permintan dan penawaran (Gong et al. 2006). Efisiensi kegiatan distribusi berpengaruh pada harga dari daging sapi yang harus dibayar oleh konsumen.

Bogor sebagai kota jasa membutuhkan pasokan dari daerah lain dalam proses pemenuhan berbagai kebutuhan, terutama kebutuhan akan komoditas pangan. Populasi sapi potong di Kota Bogor pada tahun 2010-2014 berkisar antara 177-200 ekor (PUSDATIN, 2015). Sementara itu, jumlah sapi yang dipotong di RPH milik pemerintah di Kota Bogor mencapai 1.5002.000 ekor per bulan. Hal tersebut mengindikasikan bahwa sebagian besar sapi yang dipotong di RPH Kota Bogor merupakan sapi yang berasal dari daerah lain. Saat ini pasokan sapi potong yang masuk ke Kota Bogor berasal dari wilayah Banten, Jawa Tengah, Jawa Timur, Yogyakarta dan Lampung (DITJEN PKH, 2013). Jika terjadi hambatan dalam proses pasokan dalam jaringan distribusi, maka dapat dipastikan akan terjadi kelangkaan yang menyebabkan naiknya harga daging sapi yang harus dibayar oleh konsumen. Biaya transaksi menjadi salah satu faktor penting yang perlu diketahui, karena selain berpengaruh pada pilihan saluran pemasaran juga berpengaruh terhadap harga yang harus dibayar oleh konsumen.
Daging sapi sebagai salah satu komoditas pangan utama menjadi topik penelitian yang menarik. Berbagai penelitian mengenai daging sapi telah dilakukan, seperti kajian mengenai risiko dalam rantai pasok daging sapi yang dilakukan oleh Wang et al. (2010) dan Fearne et al. (2001), optimasi dalam pengelolaan dan distribusi produk daging sapi segar dengan pendekatan rantai pasok (Rong et al. 2011) dan Van der Vorst (2009), analisis kinerja rantai pasok pada agribisnis sapi potong oleh Yayat et al. (2010) dan Ding et al. (2014), hingga mengenai langkah-langkah strategis dalam mencapai swasembada daging sapi yang diteliti oleh Matondang (2013) dan Tseuoa et al. (2012). Penelitian terdahulu berfokus dalam peningkatan kinerja rantai pasok dari sisi kualitas, penanganan risiko dan kontinuitas pasokan sedangkan pada penelitian yang dilakukan optimasi kinerja rantai pasok ditingkatkan dengan cara menganalisis biaya transaksi dan nilai tambah dalam sepanjang rantai pasok daging sapi sehingga rantai pasok akan berjalan dengan lebih efisien.

Tingginya permintaan daging sapi yang terjadi di Kota Bogor mendorong para pelaku distribusi seperti pedagang besar dan pedagang pengecer selaku perantara yang berhubungan langsung dengan konsumen untuk mengoptimalkan rantai pasokan daging sapi. Oleh karena itu, penelitian terkait dengan analisis biaya transaksi dalam jaringan distribusi rantai pasokan daging sapi di Kota Bogor penting untuk dilakukan. Penelitian ini diharapkan dapat memberikan gambaran bagi seluruh stakeholders yang terlibat dalam pemasaran daging sapi. Dengan demikian praktik bisnis dan kebijakan yang dilakukan dapat memberikan nilai tambah bagi semua pihak yang terlibat dalam proses pasokan daging sapi hingga ke konsumen akhir (Kusriatmi et al. 2014). Berdasarkan hal tersebut maka tujuan dari penelitian adalah memetakan jaringan distribusi daging sapi di Kota Bogor dan menganalisis biaya transaksi, nilai tambah dan efisiensi pemasaran dalam saluran pemasaran daging sapi di Kota Bogor.

Ruang lingkup masalah dalam penelitian ini dibatasi agar lebih terarah dan mudah dipahami. Penelitian berfokus kepada jaringan distribusi dan biaya transaksi dalam proses pasokan, mulai dari RPH (Rumah Pemotongan Hewan) hingga ke konsumen akhir di Kota Bogor. Analisis nilai tambah dilakukan pada masing-masing pelaku dalam rantai pasok daging sapi di Kota Bogor. 


\section{METODE PENELITIAN}

Lokasi penelitian berawal dari Rumah Pemotongan Hewan yang berada di Kota Bogor, akan ditelusuri pasokan yang berasal dari RPH hingga ke pasar. Penelitian dilakukan mulai dari bulan Juni 2015Desember 2015. Data yang digunakan dalam penelitian yaitu data primer dan sekunder. Data primer adalah data yang diperoleh secara langsung dari sumber datanya melalui metode pengumpulan data tertentu untuk menjawab pertanyaan penelitian, sedangkan data sekunder adalah data yang diperoleh dan dikumpulkan berdasarkan hasil studi pustaka atau sumber yang telah ada dalam rangka menjawab pertanyaan penelitian. Data sekunder diperoleh melalui penelusuran karyakarya ilmiah atau literatur dan data-data relevan yang dikeluarkan oleh lembaga pemerintah dan instansi terkait guna membantu dan mendukung ketersedian data.

Untuk melakukan pemetaan jaringan distribusi daging sapi, responden ditentukan dengan purposive sampling. Responden merupakan seseorang yang dinilai memiliki kapabilitas dan informasi mengenai jaringan distribusi daging sapi di Kota Bogor. Kerangka pemikiran penelitian disajikan pada Gambar 1.

Setelah melakukan wawancara mendalam dengan responden ahli, peneliti mengikuti alur saluran pemasaran dari pedagang daging sapi di Kota Bogor dengan cara snowball sampling. Penelitian dimulai dari pedagang daging sapi yang telah terdaftar menjadi pengguna jasa RPH Kota Bogor. Responden pada penelitian ini terdiri atas 45 orang pedagang daging sapi yang tersebar di tujuh pasar tradisional di Kota Bogor, yaitu Pasar Anyar, Pasar Bogor, Pasar Merdeka, Pasar Sukasari, Pasar Jambu Dua, Pasar Gunung Batu dan Pasar Padasuka.

Pada penelitian ini jaringan distribusi rantai pasokan daging sapi dipetakan dengan menggunakan Value Stream Mapping (VSM) (Rother et al. 1999). VSM merupakan suatu metode untuk menggambarkan aliran informasi, aliran produk dan aliran keuangan dalam suatu rantai pasok. Proses suatu pasokan digambarkan secara berurutan hingga sampai ke konsumen akhir. Untuk analisis biaya transaksi, penarikan kesimpulan dapat dilihat berdasarkan perbandingan nilai efisiensi pemasaran (EP) dimana rantai pasokan yang memiliki tingkat efisiensi pemasaran lebih tinggi adalah rantai pasokan yang memiliki nilai EP lebih kecil. Rumus efisiensi pemasaran dapat dilihat sebagai berikut (Emhar et al. 2014)

\section{Efisiensi Pemasaran $(\%)=\mathrm{TB} / \mathrm{TNP} \times 100$}

Keterangan:

TB : Total Biaya

TNP : Total Nilai Produk

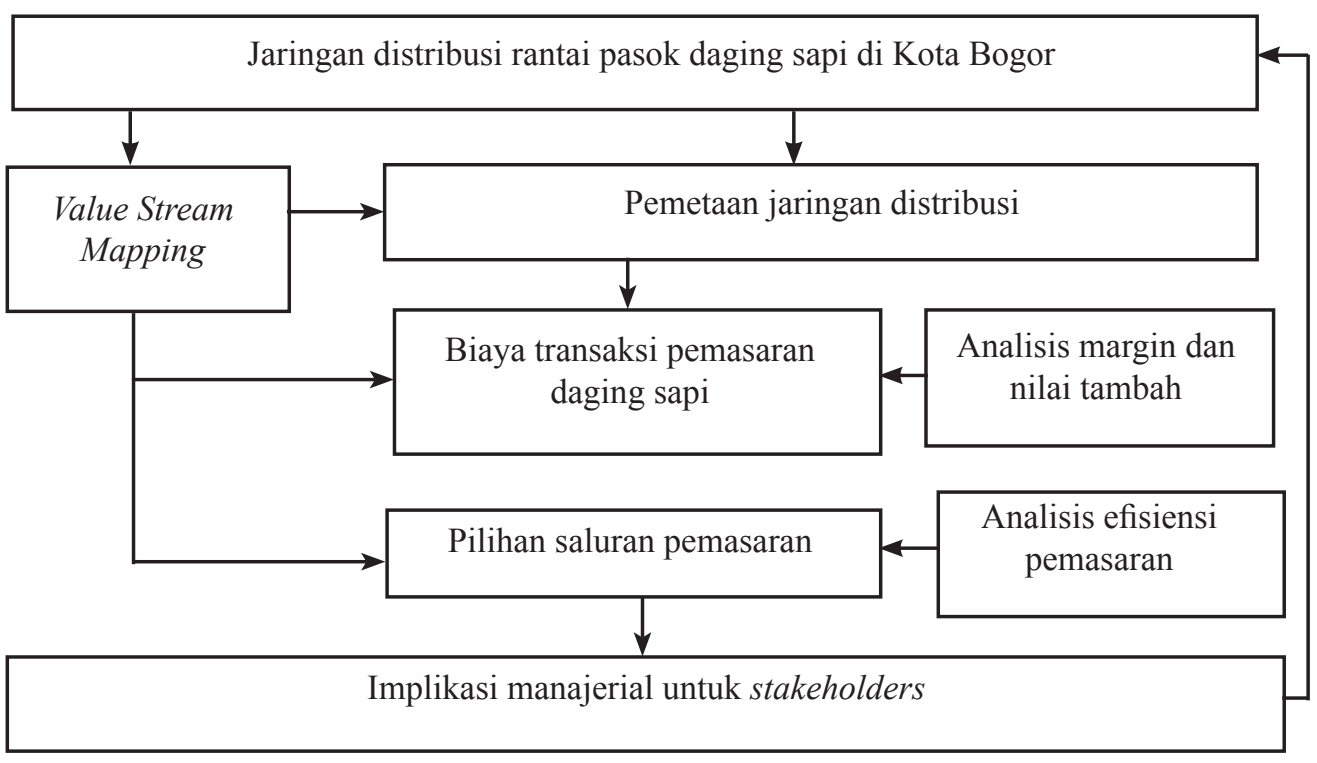

Gambar 1. Kerangka pemikiran penelitian 
Langkah selanjutnya untuk mengetahui efisiensi pemasaran dapat dilihat berdasarkan nilai distribusi margin pemasaran pada rantai pasokan daging sapi. Pengujian dapat dilakukan dengan menggunakan analisis margin pemasaran dan distribusi margin. Berikut adalah rumus untuk perhitungan margin pemasaran dan distribusi margin pemasaran (Rahim dan Hastuti, 2007):

\section{Margin pemasaran (rupiah per kg) $=$ Pr-Pf}

Keterangan :

$\operatorname{Pr}$ : harga di tingkat konsumen daging (rupiah per $\mathrm{kg}$ )

Pf : harga di tingkat pengusaha daging (rupiah per kg)

Rumus distribusi margin pemasaran daging sapi dibagi menjadi dua, yaitu share biaya dan share keuntungan:

Share biaya:

$$
\mathrm{SBij}=[\mathrm{Cij} /(\mathrm{Pr}-\mathrm{Pf})] \times 100 \%
$$

Share keuntungan:

$$
\begin{gathered}
\mathrm{SKj}=[\mathrm{Pij} /(\mathrm{Pr}-\mathrm{Pf})] \times 100 \% \\
\mathrm{Pij}=\mathrm{HJj}-\mathrm{HBj}-\mathrm{Cij}
\end{gathered}
$$

Keterangan :

$\mathrm{SB}_{\mathrm{ij}}$ : persentase biaya untuk melaksanakan fungsi pemasaran ke-i oleh lembaga pemasaran ke-j (\%).

Cij : biaya untuk melaksanakan fungsi pemasaran ke-i oleh lembaga pemasaran ke-j (rupiah per kg)

SKj : persentase keuntungan lembaga pemasaran ke-j $(\%)$

Pij : keuntungan lembaga pemasaran ke-j (rupiah per kg)

$\mathrm{HJj} \quad$ : harga jual lembaga pemasaran ke-j (rupiah per kg)

$\mathrm{HBj}$ harga beli lembaga pemasaran ke-j (rupiah per $\mathrm{kg}$ )

Nilai margin pemasaran digunakan untuk mengetahui nilai share biaya dan share keuntungan setiap mata rantai. Penarikan kesimpulan dilakukan dengan melihat shared value yang berkaitan dengan penerimaan nilai sebagai timbal balik dari kontribusi yang diberikan setiap mata rantai (Emhar et al. 2014). Metode Hayami digunakan untuk menganalisis biaya transaksi dan nilai tambah pada rantai pasok. Adapun prosedur perhitungan analisis nilai tambah dengan metode Hayami dapat

\begin{tabular}{|c|c|c|}
\hline No & Variabel & Nilai \\
\hline \multicolumn{3}{|c|}{ Output, Input, dan Harga } \\
\hline \multirow[t]{5}{*}{1} & Output & \\
\hline & Volume penjualan & \\
\hline & $\begin{array}{l}\text { a. Primary product (daging sapi) } \\
(\mathrm{kg} / \mathrm{ekor})\end{array}$ & \\
\hline & b. Total volume penjualan (Rp/ekor) & \\
\hline & c. Total nilai penjualan (Rp/ekor) & (1d) \\
\hline \multirow[t]{2}{*}{2} & a. Volume bahan baku (kg/ekor) & $(2 a)$ \\
\hline & b. Nilai bahan baku (Rp/ekor) & $(2 b)$ \\
\hline 3 & Tenaga kerja langsung (HOK/ekor) & (3) \\
\hline 4 & Faktor konversi & $(4)=(1 d) /(2 b)$ \\
\hline 5 & $\begin{array}{l}\text { Koefisien tenaga kerja langsung } \\
(\mathrm{HOK} / \mathrm{Kg})\end{array}$ & $(5)=(3) /(2 a)$ \\
\hline 6 & Harga output (Rp/Kg) & $(6)$ \\
\hline 7 & $\begin{array}{l}\text { Upah tenaga kerja langsung ( } \mathrm{Rp} / \\
\mathrm{HOK})\end{array}$ & (7) \\
\hline \multicolumn{3}{|c|}{ Penerimaan dan Keuntungan } \\
\hline 8 & Harga bahan baku (Rp/Kg) & $(2 a) /(2 b)$ \\
\hline 9 & Harga input lain (Rp/kg) & $(9)$ \\
\hline 10 & Nilai output (Rp/kg) & $(10)=(4) \times(6)$ \\
\hline
\end{tabular}
dilihat pada Tabel 1 .

\begin{tabular}{|c|c|c|}
\hline No & Variabel & Nilai \\
\hline \multirow[t]{2}{*}{11} & a. Nilai tambah $(\mathrm{Rp} / \mathrm{kg})$ & $\begin{array}{c}(11 a)=(10)= \\
(8)-(9)\end{array}$ \\
\hline & b. Rasio nilai tambah (\%) & $\begin{array}{l}(11 \mathrm{~b})=(11 \mathrm{a}) / \\
(10) \times 100\end{array}$ \\
\hline \multirow[t]{2}{*}{12} & $\begin{array}{l}\text { a. Pendapatan tenaga kerja langsung } \\
(\mathrm{Rp} / \mathrm{kg})\end{array}$ & $(12 a)=(5) x(7)$ \\
\hline & $\begin{array}{l}\text { b. Pangsa tenaga kerja langsung } \\
\qquad(\%)\end{array}$ & $\begin{array}{l}(12 \mathrm{~b})=(12 \mathrm{a}) / \\
(14) \times 100\end{array}$ \\
\hline \multirow[t]{2}{*}{13} & a. Keuntungan $(\mathrm{Rp} / \mathrm{kg})$ & $\begin{array}{l}(13 a)=(11 a)- \\
\quad(12 a)\end{array}$ \\
\hline & b. Tingkat keuntungan (\%) & $\begin{array}{l}(13 b)=(13 a) / \\
(10) \times 100\end{array}$ \\
\hline \multicolumn{3}{|c|}{ Balas Jasa Pemilik Faktor Produksi } \\
\hline \multirow[t]{4}{*}{14} & $\operatorname{Marjin}(\mathrm{Rp} / \mathrm{kg})$ & \\
\hline & $\begin{array}{l}\text { a. Pendapatan tenaga kerja langsung } \\
\text { (\%) }\end{array}$ & $(14)=(10)-(8)$ \\
\hline & b. Sumbangan input lain (\%) & $\begin{array}{c}(14 a)=(12 a) / \\
(14) \times 100\end{array}$ \\
\hline & c. Keuntungan perusahaan (\%) & $\begin{array}{l}(14 \mathrm{c})=(13 \mathrm{a}) / \\
(14) \times 100\end{array}$ \\
\hline
\end{tabular}

Tabel 1. Prosedur perhitungan analisis nilai tambah dengan metode Hayami 


\section{HASIL}

\section{Jaringan Distribusi Rantai Pasok Daging Sapi di Kota Bogor}

Struktur jaringan distribusi daging sapi pada umumnya memiliki beberapa karakteristik yang sama. Jaringan distribusi daging sapi yang terdapat di Kota Bogor umumnya mengikuti pola seperti yang ditunjukan dalam VSM yang disajikan pada Gambar 2.

Berdasarkan VSM pada Gambar 1, terdapat sembilan alternatif saluran pemasaran daging sapi di Kota Bogor, yaitu sebagai berikut:

1. Peternak lokal - Pedagang Sapi Hidup - Pedagang Besar Daging Sapi I - Konsumen

2. Peternak lokal - Pedagang Sapi Hidup - Pedagang Besar Daging Sapi I - PBDS II - Konsumen

3. Peternak lokal - Pedagang Sapi Hidup - Pedagang Besar Daging Sapi I - PBDS II - Pedagang Pengecer - Konsumen

4. Feedloter-Pedagang Sapi Hidup - Pedagang Besar Daging Sapi I - Konsumen
5. Feedloter - Pedagang Sapi Hidup - Pedagang Besar Daging Sapi I - PBDS II - Konsumen

6. Feedloter-Pedagang Sapi Hidup - Pedagang Besar Daging Sapi I - PBDS II - Pedagang Pengecer Konsumen

7. Feedloter - Pedagang Besar Daging Sapi I Konsumen

8. Feedloter - Pedagang Besar Daging Sapi I Pedagang Besar Daging Sapi II - Konsumen

9. Feedloter - Pedagang Besar Daging Sapi I Pedagang Besar Daging Sapi II - Pedagang Pengecer - Konsumen

Rata- rata waktu yang dibutuhkan untuk proses distribusi daging sapi mulai dari feedloter atau peternak lokal hingga sampai ke konsumen (lead time) adalah 21 jam. Proses transportasi sapi hidup ke RPH merupakan kegiatan yang memakan waktu paling lama, yaitu 20 jam atau $90 \%$ dari total lead time. Value added time pada jaringan distribusi daging sapi sebesar 13 jam. Aktifitas penambahan nilai terjadi di Rumah Pemotongan Hewan, yaitu penyembelihan sapi hidup menjadi karkas (daging sapi).

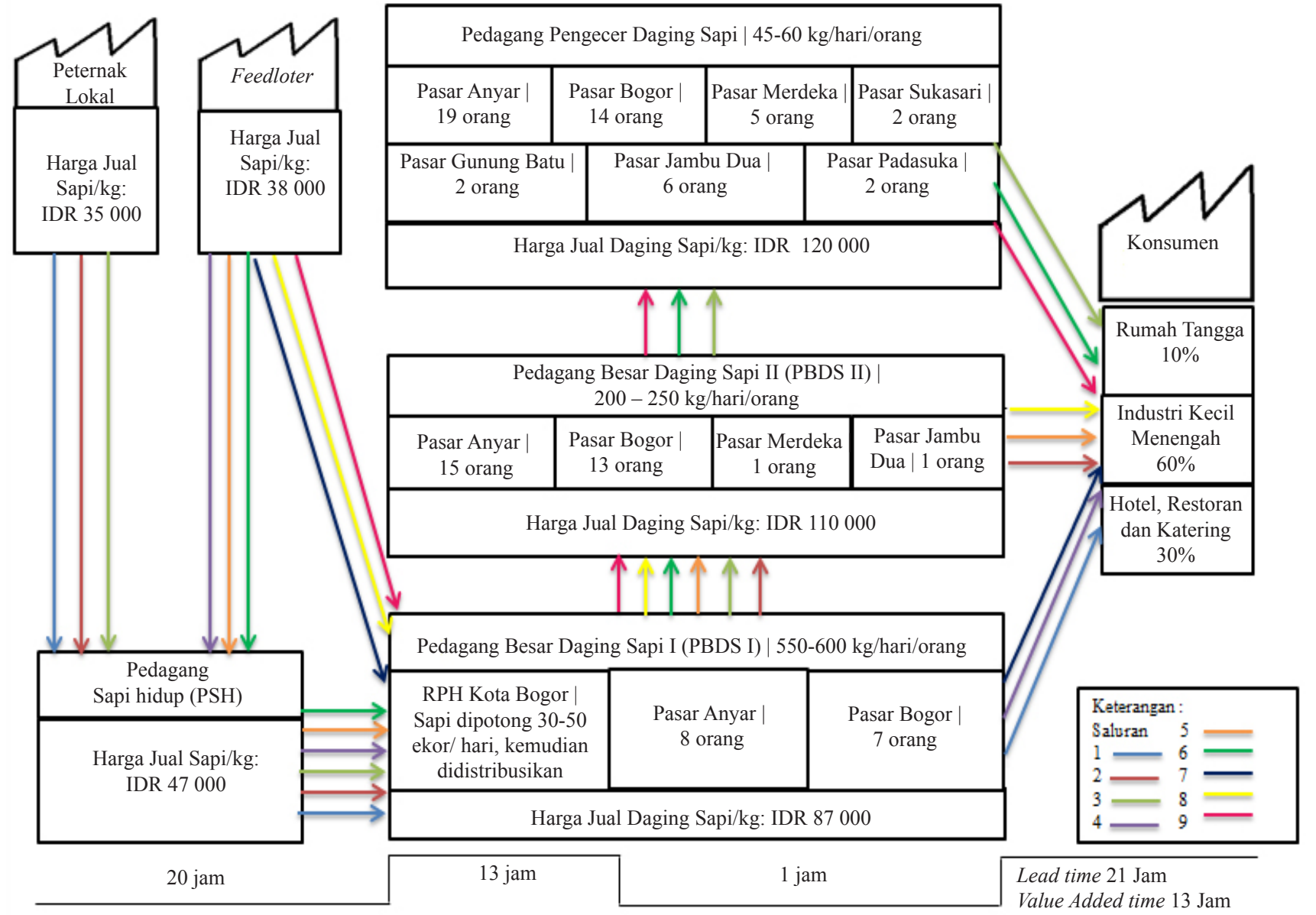

Gambar 2. Value stream mapping saluran pemasaran daging sapi di kota bogor 


\section{Aliran Produk Pada Jaringan Distribusi Daging Sapi}

Aliran produk merupakan aliran komoditas mulai dari hulu (upstream) dalam bentuk sapi hidup hingga ke hilir dalam bentuk daging (downstream). Berdasarkan wawancara dengan pihak RPH, sapi yang diimpor mayoritas berasal dari Australia. Berdasarkan Gambar 2, dapat diketahui bahwa aliran jaringan distribusi produk sapi hidup yang didapatkan oleh Pedagang Besar Daging Sapi I (PBDS I) mempunyai dua alternatif, yaitu dipasok oleh Pedagang Sapi Hidup atau membeli langsung dari feedloter. PBDS I merupakan pedagang besar daging sapi yang pasokan awalnya berupa sapi hidup, kemudian dibawa ke Rumah Pemotongan Hewan (RPH) untuk dipotong menjadi karkas yang kemudian didistribusikan ke Pasar di Kota Bogor. Jumlah sapi yang dipotong oleh masing-masing PBDS I berkisar antara satu ekor hingga 10 ekor, disesuaikan dengan prediksi jumlah permintaan pasar.

Hasil wawancara dengan pihak RPH Terpadu Kota Bogor, rata-rata jumlah sapi yang dipotong dalam satu hari sebanyak 50 ekor. Kapasitas penampungan di RPH mampu menampung Sapi hidup sebanyak 400 ekor. Waktu tunggu sapi hingga dipotong maksimal lima hari terhitung sejak sapi tersebut masuk ke RPH. Sapi yang telah dipotong dan telah berbentuk karkas, selanjutnya akan didistribusikan oleh PBDS I. PBDS I akan mendistribusikan daging sapi ke Pedagang Besar Daging Sapi II (PBDS II) atau langsung memasok kebutuhan konsumen akhir dengan pasokan yang cukup besar, seperti Industri Kecil Menengah (IKM) atau Hotel, Restoran, dan Katering (Horeka). PBDS II merupakan pedagang besar daging yang membeli karkas dari PBDS I dalam jumlah pasokan berkisar antara 100 kg hingga $250 \mathrm{~kg} /$ hari dengan pengalaman berdagang lebih dari satu tahun. PBDS I mendistribusikan daging sapi ke PBDS II yang terdapat di pasar yang terdapat di Kota Bogor, beberapa wilayah di Kabupaten Bogor dan sekitarnya.

Pasar di Kota Bogor, dikelola oleh Perusahaan Daerah Pasar Pakuan Jaya. Terdapat tiga kriteria pasar, yaitu pasar besar, pasar sedang dan pasar kecil. Kriteria tersebut dikategorikan berdasarkan luas pasar dan jumlah pedagang yang terdapat di dalam pasar tersebut. Pasar besar di Kota Bogor adalah Pasar Anyar dan Pasar Bogor, pasar sedang di Kota Bogor adalah Pasar Jambu Dua, Pasar Merdeka dan Pasar Sukasari, sedangkan yang termasuk Pasar Kecil adalah Pasar Gunung
Batu dan Pasar Padasuka. PBDS II mendistribusikan dagingnya ke pedagang pengecer maupun langsung ke konsumen akhir seperti IKM, Horeka atau Konsumen Rumah Tangga. Pedagang Pengecer (PP) baik di pasar besar, pasar sedang atau pasar kecil, mendapat pasokan daging sapi dari PBDS II, pasokannya dapat diantar atau diambil dari PBDS II sesuai dengan kesepakatan yang telah ditetapkan.

\section{Aliran Keuangan Pada Jaringan Distribusi Daging Sapi}

Aliran keuangan, merupakan perpindahan uang yang mengalir dari hilir ke hulu. Aliran keuangan mengalir dari konsumen hingga ke peternak sapi potong hidup. Aliran keuangan juga mengalir dari pedagang sapi ke feedloter. Pembayaran terhadap pembelian sapi potong dilakukan secara langsung di feedlot dimana sapi potong itu diperoleh. Pembelian sapi bisa dilakukan secara tunai maupun secara kredit. Perbedaan sistem pembelian ini dipengaruhi oleh kemampuan modal pembeli sapi, karena harga sapi saat ini relatif mahal. Sistem pembayaran pada pembelian sapi bisa dilakukan secara kredit sesuai dengan kesepakatan antara feedloter dan pedagang sapi. Terdapat pedagang sapi yang membeli sapi secara putus, terdapat pula pedagang sapi yang sudah menjadi kepercayaan feedloter dan hanya membayar sesuai dengan jumlah sapi yang sudah terjual. Aliran keuangan mengalir dari pedagang pengecer mengalir ke pedagang besar daging sapi. Terdapat dua jenis pembayaran yaitu pembayaran tunai diawal dan pembayaran tunai diakhir. Pembayaran tunai diawal artinya pedagang pengecer melakukan pembayaran sesuai dengan jumlah daging sapi yang dibeli, sedangkan pada sistem pembayaran di akhir artinya pedagang pengecer melakukan pembayaran setelah daging terjual.

\section{Aliran Informasi pada Jaringan Distribusi Daging Sapi}

Aliran informasi merupakan aliran yang terjadi secara timbal balik, baik dari hulu ke hilir atau hilir ke hulu. Informasi yang mengalir berkaitan dengan stok sapi hidup,jumlah permintaan, harga sapi hidup, harga daging sapi maupun informasi terkait kebijakan dan peraturan dalam tata niaga daging sapi. Aliran informasi mengalir secara vertikal dan horizontal (Chopra dan Meindl, 2007). Pada aliran vertikal terdapat koordinasi pada mata rantai yang berbeda, yaitu antara peternak, feedloter, pedagang sapi, RPH, pedagang besar daging, pedagang 
pengecer dan konsumen. Pada aliran horizontal terjadi koordinasi pada sesama anggota mata rantai. Aliran informasi yang terjadi antara feedloter dan pedagang sapi berkaitan dengan jumlah sapi yang dibutuhkan oleh pedagang sapi untuk memenuhi kebutuhan konsumen. Kecocokan harga dan kondisi sapi yang dibeli menjadi objek utama dalam komunikasi yang terjalin antara pedagang sapi dan feedloter. Walaupun demikian, tidak terikat dengan kontrak pedagang sapi pada umumnya sudah mempunyai langganan tersendiri, jika feedlot langganannya tidak mempunyai stok yang sesuai dengan keinginan pedagang, baru pedagang tersebut akan mencari feedloter yang lain.

Aliran informasi yang mengalir antara pedagang sapi dan pedagang besar daging sapi terkait dengan jumlah permintaan terhadap sapi yang siap dipotong di RPH. Aliran informasi antara pedagang besar dengan pedagang pengecer terkait dengan jumlah daging sapi yang akan diminta oleh pedagang pengecer untuk dijual lagi ke konsumen. Informasi yang mengalir khususnya dari pedagang pengecer yang melakukan sistem pembayaran di akhir, berkaitan dengan jumlah daging sapi yang terjual setiap harinya. Aliran informasi yang mengalir dari pedagang besar ke pedagang pengecer berkaitan dengan jumlah stok daging sapi dan harga daging sapi di tingkat pedagang pengecer. Konsumen daging sapi adalah orang yang melakukan pembelian terhadap daging sapi baik konsumen akhir maupun konsumen yang akan membeli daging dengan tujuan untuk dijual kembali setelah diolah. Konsumen daging sapi di Kota Bogor sebagian besar merupakan industri kecil menengah (60\%) disusul dengan Horeka (30\%) dan konsumen rumah tangga (10\%).

\section{Biaya Transaksi dalam Jaringan Distribusi Daging Sapi di Kota Bogor}

Hasil pemetaan jaringan distribusi daging sapi, terdapat sembilan pilihan saluran pemasaran di Kota Bogor. Dari masing-masing saluran pemasaran tersebut dianalisis tingkat efisiensi dan distribusi marginnya untuk mengetahui saluran pemasaran yang paling efisien dan paling tinggi nilai rasio keuntungannya. Hasil perhitungan tingkat efisiensi pemasaran dan distribusi margin dapat dilihat pada Tabel 2. Hasil perhitungan efisiensi pemasaran daging sapi dapat dilihat bahwa seluruh saluran pemasaran daging sapi di Kota Bogor sudah efisien, karena hasil perhitungan nilai efisiensi pemasaran seluruhnya jauh berada dibawah 50\%. Berdasarkan hasil perhitungan efisiensi pemasaran, saluran dengan nilai efisiensi yang paling tinggi adalah saluran $7(0,80 \%)$. Saluran 7 (Feedloter - PBDS I - Konsumen) sangat efisien dan menguntungkan. Namun, membutuhkan modal yang cukup besar, baik untuk membeli sapi hidup secara langsung di feedloter maupun biaya transaksi yang diperlukan dalam saluran pemasaran tersebut. Saluran 9 (Feedloter - PBDS I - PBDS II - Pedagang Pengecer - Konsumen) merupakan salah satu saluran dengan proses pasokan yang cukup panjang. Namun, saluran ini termasuk kepada saluran yang paling efisien jika dilihat dari nilai EP sebesar 0,87\%. Saluran ini cukup efisien, karena jumlah pasokan rata-rata pada saluran ini hanya sebesar $40,83 \mathrm{~kg} /$ hari dengan biaya transaksi Rp1.048/kg, sementara total nilai produknya mencapai Rp120.000/ kg. Pedagang pengecer daging sapi di Kota Bogor yang sebagian besar merupakan pedagang pengecer memilih saluran ini dengan alasan biaya transaksi rendah dan kemampuan untuk membeli pasokan daging sapi yang terbatas.

Tabel 2. Hasil perhitungan tingkat efisiensi pemasaran dan distribusi margin

\begin{tabular}{ccccc}
\hline Saluran & Rata - rata VP (kg) & $\begin{array}{c}\text { Rata- rata } \\
\text { nilai produk Rp/kg (a) }\end{array}$ & $\begin{array}{c}\text { Rata-rata } \\
\text { biaya transaksi Rp/kg (b) }\end{array}$ & $\begin{array}{c}\text { Rata-rata EP } \\
\text { (c)=(b)/(a) }\end{array}$ \\
\hline 1 & 550 & 87.000 & 829 & $0,95 \%$ \\
2 & 216,67 & 100.000 & 1.145 & $1,14 \%$ \\
3 & 37,5 & 120.000 & 1.384 & $1,15 \%$ \\
4 & 430 & 87.000 & 712 & $0,82 \%$ \\
5 & 200 & 100.000 & 978 & $0,98 \%$ \\
6 & 42,5 & 120.000 & 1.099 & $0,92 \%$ \\
7 & 566,67 & 87.000 & 694 & $0,80 \%$ \\
8 & 212,5 & 100.000 & 1.004 & $1,04 \%$ \\
9 & 40,83 & 120.000 & 1.048 & $0,87 \%$ \\
\hline
\end{tabular}

Keterangan:

$\mathrm{VP}=$ Volume pasokan $\mathrm{EP}=$ Efisiensi pemasaran 
Saluran dengan biaya transaksi paling tinggi adalah saluran 3 (Peternak lokal - Pedagang Sapi Hidup PBDS I- PBDS II - Pedagang Pengecer - Konsumen). Saluran 3 merupakan salah satu saluran yang paling panjang diantara 9 alternatif saluran pemasaran. Panjangnya rantai pasokan menjadikan biaya transaksi menjadi semakin tinggi. Saluran 3 ini digunakan oleh pedagang pengecer daging sapi dengan rata-rata volume pasokan yang paling rendah, yaitu sebanyak $37,5 \mathrm{~kg} /$ hari. Sementara itu, saluran dengan biaya transaksi paling rendah adalah saluran 7 . Salah satu faktor yang menyebabkan saluran 7 menjadi saluran dengan tingkat efisiensi yang tinggi dan paling menguntungkan adalah biaya transaksi yang rendah. Rata-rata volume pasokan harian yang tinggi yaitu sebesar $566,67 \mathrm{~kg}$ /hari juga menjadikan biaya transaksi/kg semakin efisien. Setelah menganalisis biaya transaksi pada masing-masing saluran pemasaran, nilai tambah dianalisis pada masingmasing jenis pedagang daging sapi yang terdapat di Kota Bogor. Perhitungan nilai tambah dengan menggunakan metode hayami disajikan pada Tabel 3.

Tabel 3. Perhitungan nilai tambah dengan metode hayami

\begin{tabular}{|c|c|c|c|c|}
\hline \multirow{2}{*}{ No } & \multirow{2}{*}{ Variabel } & \multicolumn{3}{|c|}{ Nilai } \\
\hline & & Pedagang besar I & Pedagang besar II & Pedagang pengecer \\
\hline & Output, Input dan Harga & & & \\
\hline 1 & Output $(\mathrm{kg})=(\mathrm{a})$ & 400 & 250 & 34,32 \\
\hline 2 & Input bahan baku $(\mathrm{kg})=(\mathrm{b})$ & 700 & 250 & 34,32 \\
\hline 3 & Input tenaga kerja $(\mathrm{HOK})=(\mathrm{c})$ & 4 & 2 & 1 \\
\hline 4 & Faktor konversi $=(d)=(a) /(b)$ & 0,57 & 1 & 1 \\
\hline 5 & Koefisien TKL $(\mathrm{HOK} / \mathrm{kg})=(\mathrm{e})=(\mathrm{c}) /(\mathrm{b})$ & 0,006 & 0,008 & 0,029 \\
\hline 6 & Harga output $(\mathrm{Rp} / \mathrm{kg})=(\mathrm{f})$ & 87.000 & 110.000 & 120.000 \\
\hline \multirow[t]{2}{*}{7} & Rata-rata upah tenaga kerja $(\mathrm{Rp} / \mathrm{HOK})=(\mathrm{g})$ & 80.000 & 50.000 & 30.000 \\
\hline & Penerimaan dan Keuntungan (Rp/kg Bahe & ku) & & \\
\hline 8. & Harga input $(\mathrm{Rp} / \mathrm{kg})=(\mathrm{h})$ & 38.000 & 87.000 & 110.000 \\
\hline \multirow[t]{8}{*}{9.} & Sumbangan input lain (biaya transaksi) & & & \\
\hline & Biaya transportasi $(\mathrm{Rp} / \mathrm{kg})$ & 357,14 & 200 & 145,68 \\
\hline & Biaya RPH (Rp/kg) & 142,85 & & \\
\hline & Biaya retribusi pasar $(\mathrm{Rp} / \mathrm{kg})$ & 0,85 & 24 & 174,82 \\
\hline & Biaya listrik $(\mathrm{Rp} / \mathrm{kg})$ & 5,71 & 16 & 116,55 \\
\hline & Biaya sewa kios/hari (Rp/kg) & 1,58 & 4,44 & 32,05 \\
\hline & Biaya lain-lain $(\mathrm{Rp} / \mathrm{kg})$ & 50 & 80 & 291,37 \\
\hline & Total biaya transaksi $(\mathrm{Rp} / \mathrm{kg})=(\mathrm{i})$ & 558.13 & 324.44 & 760,33 \\
\hline 10. & Nilai output $(\mathrm{Rp} / \mathrm{kg})=(\mathrm{j})=(\mathrm{d}) \times(\mathrm{f})$ & 49.590 & 100.000 & 120.000 \\
\hline \multirow[t]{2}{*}{11.} & Nilai tambah $(\mathrm{Rp} / \mathrm{kg})=(\mathrm{k})=(\mathrm{j})-(\mathrm{i})-(\mathrm{h})$ & $11.031,87$ & $12.675,56$ & $9.239,67$ \\
\hline & Rasio nilai tambah $=(\mathrm{l})=(\mathrm{k}) /(\mathrm{j})$ & $22,24 \%$ & $12,67 \%$ & $7,6 \%$ \\
\hline \multirow[t]{2}{*}{12.} & Pendapatan tenaga kerja $=(\mathrm{m})=(\mathrm{e}) \times(\mathrm{g})$ & 480 & 400 & 870 \\
\hline & Imbalan tenaga kerja $=(\mathrm{n})=(\mathrm{m}) /(\mathrm{k})$ & $4,3 \%$ & $3,5 \%$ & $9,4 \%$ \\
\hline \multirow[t]{3}{*}{13.} & Keuntungan $=(\mathrm{o})=(\mathrm{k})-(\mathrm{m})$ & $10.551,87$ & $12.275,56$ & $8.369,67$ \\
\hline & Tingkat keuntungan $=(\mathrm{p})=(\mathrm{o}) /(\mathrm{j})$ & $21,27 \%$ & $12,27 \%$ & $6,9 \%$ \\
\hline & Balas Jasa Faktor Produksi (Rp/kg Bahan & & & \\
\hline \multirow[t]{4}{*}{14.} & $\operatorname{Marjin}(\mathrm{Rp} / \mathrm{kg})=(\mathrm{q})=(\mathrm{j})-(\mathrm{h})$ & 11.590 & 13.000 & 10.000 \\
\hline & Pendapatan TKL $(\%)=(\mathrm{r})=(\mathrm{m}) /(\mathrm{q})$ & $4,14 \%$ & $1,73 \%$ & $8,7 \%$ \\
\hline & Sumbangan input lain $(\%)=(\mathrm{s})=(\mathrm{i}) /(\mathrm{q})$ & $4,81 \%$ & $1,41 \%$ & $7,6 \%$ \\
\hline & Keuntungan perusahaan $(\%)=(\mathrm{t})=(\mathrm{o}) /(\mathrm{q})$ & $91,04 \%$ & $96,85 \%$ & $83,69 \%$ \\
\hline
\end{tabular}


Hasil perhitungan nilai tambah dengan menggunakan metodehayami, nilaitambahyang didapatkanolehPBDS I sebesar sebesar Rp11.031,87/ $\mathrm{kg}(22,24 \%)$. Sementara itu, PBDS II mendapatkan nilai tambah sebesar Rp12.675,56/kg (12,67\%) dan pedagang pengecer sebesar Rp9.239,67/kg (7,6\%). Nilai tambah paling besar diperoleh oleh PBDS I dari aktivitas pemotongan sapi hidup menjadi daging sapi yang dilakukan di Rumah Pemotongan Hewan (RPH). Begitupula dengan tingkat keuntungan yang diperoleh, PBDS I masih menjadi pelaku pasokan yang mendapatkan keuntungan yang paling tinggi dibandingkan dengan pelaku pasokan yang lain. Keuntungan yang diperoleh PBDS I mencapai $21,27 \%$ dari total nilai output. Biaya transaksi yang dihitung dalam analisis nilai tambah terdiri atas biaya transportasi, biaya RPH, upah jagal, retribusi pasar, biaya listrik, air dan kebersihan, biaya sewa kios, dan biaya lain-lain. PBDS I menanggung biaya transaksi paling besar dibandingkan dengan PBDS II dan Pedagang Pengecer.

\section{Implikasi Manajerial}

Hasil penelitian, implikasi manajerial yang dapat diberikan bagi pedagang daging sapi, jika ingin mendapatkan keuntungan dan efisiensi pemasaran yang tinggi dapat menggunakan saluran 7 (Feedloter - PBDS I - Konsumen) sebagai PBDS I. Tentunya pilihan ini harus didukung dengan pendanaan serta kemampuan dalam mengakses informasi mengenai jumlah permintaan daging yang dibutuhkan oleh konsumen, sehingga tidak terjadi kelebihan atau kekurangan pasokan. Seluruh stakeholder diharapkan mampu menerapkan konsep five principle of lean thinking (Womack dan Jones, 2003) dalam meningkatkan efisiensi dalam proses distribusi daging sapi di Kota Bogor, yaitu memahami makna dari nilai yang diinginkan oleh konsumen, membuat, mengatur dan melakukan perbaikan sepanjang aliran nilai; optimalisasi aliran produk, aliran keuangan dan aliran informasi yang terus mengalir dengan mengeliminasi waste dalam antrian, proses transportasi, serta berbagai kegiatan lain yang menimbulkan tingginya biaya transaksi dan menyebabkan mahalnya harga ditingkat konsumen; memberdayakan (empower) setiap pelaku dalam aliran untuk melakukan lean improvement untuk meningkatkan efisiensi dalam setiap proses pasokan; melakukan perbaikan secara terus menerus dengan menerapkan konsep plan-do-check-act dalam menyelesaikan setiap permasalahan dalam proses pasokan. Konsep lean merupakan strategi bisnis jangka panjang. Artinya, bukan merupakan suatu inisiatif taktis dalam melakukan penghematan biaya. Lean improvement dihasilkan dari setiap perubahan kecil yang dilakukan pada setiap proses pasokan menuju aliran nilai yang lebih efisien dan menguntungkan.

\section{KESIMPULAN DAN SARAN}

\section{Kesimpulan}

Hasil pemetaan jaringan distribusi dengan menggunakan VSM terdapat sembilan alternatif saluran pemasaran daging sapi di Kota Bogor. Nilai tambah terbesar diperoleh dari hasil pemotongan sapi hidup menjadi karkas yang didapatkan oleh PBDS I. Biaya transaksi dalam proses pasokan jaringan distribusi hanya berkisar $3-5 \%$, biaya yang mendominasi adalah biaya dalam membeli pasokan daging sapi yang mencapai $60 \%$. Saluran yang memiliki nilai efisiensi pemasaran tertinggi $(0,80 \%)$ dan biaya transaksi terendah (Rp694/kg) adalah saluran 7, yaitu (Feedloter - PBDS I - Konsumen).

\section{Saran}

Hasil penelitian, biaya transaksi yang ditanggung oleh masing-masing pedagang daging sapi hanya berkisar $3-5 \%$ dari harga daging sapi yang harus dibayar oleh konsumen. Presentase keuntungan yang didapatkan oleh pedagang dari harga daging sapi sebesar 10-30\% dan sisanya yang mendominasi hingga $60 \%$ merupakan biaya untuk menanggung harga pokok dari daging sapi tersebut. Karena penelitian ini dimulai dari RPH maka diperlukan penelitian lanjutan mengenai penyebab mahalnya harga pokok dari daging sapi tersebut, terutama dari proses pengadaan sapi yang mayoritas berasal dari luar Kota Bogor

\section{DAFTAR PUSTAKA}

Aisyah SA, Sanim B, Maulana A. 2013. Strategi pengembangan usaha sapi potong: studi kasus CV. Mitra Tani Farm. Jurnal Manajemen \& Agribisnis 10(2): 109-116.

Chopra S, Meindl P. 2007. Supply Chain Management, Strategy, Planning, and Operations. Third Edition. New Jersey: Pearson Education, Inc. https://doi.org/10.1007/978-3-8349-9320-5_22.

Ding MJ, Jie F, Parton KA, Matanda MJ. 2014. 
Relationships between quality of information sharing and supply chain food quality in the Australian beef processing industry. International Journal of Logistic Management 25(1): 85-108. https://doi.org/10.1108/IJLM-07-2012-0057.

[DITJEN PKH] Direktorat Jenderal Peternakan dan Kesehatan Hewan. 2013. Statistik Peternakan dan Kesehatan Hewan Livestock and Animal Health Statistics 2013. Jakarta: Direktorat Jenderal Peternakan dan Kesehatan Hewan Kementrian Pertanian.

Emhar A, JMM Aji, T Agustina. 2014. Analisis rantai pasokan (supply chain) daging sapi di Kabupaten Jember. Berkala Ilmiah Pertanian 1(3): 55-61.

Fearne A, Hornibrook S, Dedman S. 2001. The management of perceived risk in the food supply chain: comparative study of retailer-led beef quality assurance schemes in Germany and Italy. International Food and Agribusiness Management Review 4:19-36. https://doi. org/10.1016/S1096-7508(01)00068-4.

Kusriatmi, Oktaviani R, Syaukat Y,Said A. 2014. Analysis of the effects of beef import restriction policy on beef self-sufficiency in Indonesia. Journal of ISSAAS 20(1): 115-130.

Gong W, Parton K, Cox RJ, Zhou Z. 2006. Transaction costs and cattle farmers' choice of marketing channels in China. Management Research News. 30(1): 47-56. https://doi. org/10.1108/01409170710724296.

Matondang RH, Rusdiana S. 2013. Langkah-langkah strategis dalam mencapai swasembada daging sapi 2014. Jurnal Litbang Pertanian 32 (3):131139.

Rahim A, Hastuti DRD. 2007. Ekonomika Pertanian: Pengantar, Teori dan Kasus. Jakarta: Penebar Swadaya.

Rother M, Shook J,Womack J dan Jones D. 1999. Learning To See Value Stream Mapping To
Create Value and Eliminate Muda. A Lean Tool Kit Method and Workbook. Brookline, Massachusetts: Lean Enterprise Institute.

[PUSDATIN] Pusat Data dan Sistem Informasi Pertanian. 2015. Populasi Sapi Potong di Kota Bogor. Buletin Konsumsi Pangan 5(2): 24-27.

Sirait H, Limbong WH, Suryahadi. 2007. Analisis strategi pemasaran daging sapi pada CV. Duta Mandiri Abadi. Jurnal Magister Profesional Industri Kecil Menengah 2(2): 54-67.

Rong AY, Akkerman R, Grunow M. 2011.An optimization approach for managing fresh food quality throughout the supply chain. International Journal of Production Economics 131: 421-429. https://doi.org/10.1016/j.ijpe.2009.11.026.

Tseuoa T, Syaukat Y, Hakim DB. 2012. The impact of Australia and New Zealand Free Trade Agreement on the beef industry in Indonesia. Journal of ISSAAS 18(2): 70-82.

Van der Vorst JGAJ, Tromp SO, Van der Zee DJ. 2009. Simulation modelling for food supply chain redesign: integrated decision making on product quality, sustainability and logistics. International Journal of Production Research 47: 6611-6631. https://doi.org/10.1080/00207540802356747.

Wang X,Li D,O’brien C,Li Y. 2010. A production planning model to reduce risk and improve operations management. International Journal Production and Economy 124: 463-474. https:// doi.org/10.1016/j.ijpe.2009.12.009.

Womack JP, Jones DT. 2003. Lean Thinking: Banish Waste and Create Wealth in Your Corporation. Second Edition. New York: Free Press, Simon and Schuster Inc.

Yayat HF, Marimin, Harianto. 2010. Analisis kinerja rantai pasok agribisnis sapi potong : studi kasus pada PT. Kariyana Gita Utama. Jurnal Teknik. Industri Pertanian 20 (3):193-205. 